\title{
LEGALISASI ABORSI DALAM PERSPEKTIF MEDIS DAN YURIDIS
}

\author{
Khoirul Bariyyah \\ (Jurusan Syari'ah STAIN Pamekasan, Jln. Raya Panglegur Km. 04 Pamekasan, \\ Email: Erfaseri_tnic@yahoo.com) \\ Khairul Muttaqin \\ (Jurusan Syari'ah STAIN Pamekasan Jln. Raya Panglegur Km. 04 Pamekasan, \\ Email:muttaqin.ilunks@gmail.com)
}

\begin{abstract}
Abstrak:
Akhir-akhir ini, banyak perempuan yang mengakhiri kehamilannya dengan cara aborsi. Setiap tahunnya data pelaku aborsi di Indonesia bukan semakin menurun namun sebaliknya. Data yang dihimpun Komnas Perlindungan Anak Indonesia (KPAI) menemukan dalam kurun waktu tiga tahun (2008-2010) kasus aborsi terus meningkat. Pada 2008 ditemukan 2 juta jiwa anak korban Aborsi, tahun 2009 naik 300.000 menjadi 2,3 juta janin yang dibuang paksa. Sementara itu, pada 2010 naik 200.000 menjadi 2,5 juta jiwa. 62,6 persen pelaku di antaranya adalah anak berusia di bawah 18 tahun. Lalu, bagaimana sebenarnya tanggapan dari pihak medis, yuridis, dan hukum Islam dalam menyelesaikan permasalahan ini? Tiga elemen ini sangat memengaruhi tindakan masyarakat. Dalam hal ini, para medis melihat bahwa aborsi hanya dapat dilakukan jika perempuan tersebut terindikasi penyakit yang mengancam hidupnya jika kehamilan itu tetap dipertahankan. Sedangkan hukum di Indonesia menindak tegas pelaku aborsi dan pada mereka yang membantu melakukan aborsi tersebut, namun aborsi juga dapat dilakukan pada korban perkosaan. Sedangkan dalam pandangan Islam, aborsi yang dilakukan secara sengaja adalah perbuatan yang benar-benar melanggar hukum apabila usia kehamilan sudah mencapai 120 hari. Tiga peraturan tersebut seharusnya dapat berkolaborasi agar mencapai keinginannya untuk mengurangi praktik aborsi, karena jika salah satunya tidak ada kesesuaian hukum dan ketidakpastian peraturan hal itu hanya akan membantu para pelaku aborsi muncul lebih banyak lagi.
\end{abstract}

\section{Kata-kata Kunci:}

Aborsi, Medis, Yuridis, Hukum Islam

al-1hkâm Vol.11 No.1 Juni 2016

DOI: http://dx.doi.org/10.19105/al-ihkam.v11i1.755 


\begin{abstract}
:
Nowdays, there were many womans stopped their pregnancy by abortion. Every year, data of prepators of abortion in Indonesia not to be decrease but going to be on the increase. Data that are collected by Komnas Perlindungan Anak Indonesia (KPAI) founds in three years (2008-2010), abortion case was going to be increase. In 2008 was found 2 million souls of child becomes the victims of abortion. In 2009, it was increase 300.000 souls become 2,3 million. While, in 2010 it was increase to 200.000 becomes 2,5 million souls have been died by abortion. $62,6 \%$ of the prepators were did by youngs people under $18^{\text {th }}$. Then, how the medical, juridical, and Islamic law responds about these problems? These three elements are very influence to the act of societies. In this case, the medical view that abortions can only be applied if the woman indicated life-threatening disease. Whereas, in Indonesian law firm action against the perpetrators of abortion and those who assist abortion. but abortion may also be performed on rape victims. Whereas, in the view of Islam, abortion is absolutely intentional unlawful if the age of the baby are 120 days and more. These three things need to collaborate in order to achieve the desire to reduce the practice of abortion, because if one of them there is not suitable law and uncertain regulations these will only help the perpetrators of abortion many more.
\end{abstract}

\title{
Key Words:
}

Abortion, Medical, Yuridical, Islamic Law

\section{Pendahuluan}

Aborsi adalah salah satu wacana aktual yang marak diperbincangkan akhir-akhir ini. Persoalan ini tidak hanya sebatas persoalan individu, namun juga sudah menjadi bagian dari persoalan sosial karena telah meresahkan masyarakat. Banyak ditemukan praktek-praktek ilegal untuk melakukan aborsi, mulai dari dukundukun dan bahkan dokter juga membuka praktek untuk melakukan aborsi. Media cetak maupun media elektronik sering kali memberitakan tentang penemuan serpihan-serpihan tubuh janin di tempat sampah, penguburan bayi hasil aborsi, dan bahkan penemuan bayi di pinggir jalan, di kolong jembatan tanpa diketahui siapa 
pemilik bayi tersebut. Data yang ditemukan oleh Erick Eckholm,1 hampir setiap tahun sekurang-kurangnya 35 juta sampai 55 juta perempuan di seluruh dunia yang mengakhiri masa kehamilannya dengan cara aborsi.

Sedangkan di Indonesia, data yang dihimpun oleh Komisi Nasional (Komnas) Perlindungan Anak Indonesia (KPAI) menemukan bahwa tahun 2008 ditemukan 2 juta jiwa anak korban Aborsi, tahun 2009 naik 300.000 menjadi 2,3 juta janin yang dibuang paksa. Sementara itu, pada 2010 naik 200.000 menjadi 2,5 juta jiwa. 62,6 persen pelaku di antaranya adalah anak berusia di bawah 18 tahun. ${ }^{2}$ Selain itu, data studi Perkumpulan Keluarga Berencana Indonesia (PKBI) di 12 kota dari tahun 2000-2011 juga menunjukkan, 73-83 persen perempuan yang ingin aborsi ialah perempuan menikah karena kegagalan kontrasepsi. ${ }^{3}$ Hal ini bukanlah angka yang kecil, namun besar. Tindakan aborsi ini tidak hanya melenyapkan keberadaan janin yang sama sekali tidak diberi kesempatan untuk menikmati kehidupan dunia, namun juga mengancam nyawa sang ibu yang mengandungnya.

Fenomena ini mengundang reaksi dari berbagai kalangan karena persoalan aborsi tidak hanya mengancam eksistensi kelangsungan hidup namun juga terkait dengan nilai-nilai kemanusiaan yang dalam konsep agama sangat dijunjung tinggi. Oleh karena itu, perlu adanya penanganan yang arif dan bijaksana dalam menanggulangi permasalahan tersebut. Dari latar belakang inilah penulis tertarik untuk menulis topik tentang permasalahan aborsi ini baik dalam perspektif medis maupun yuridis sehingga dapat ditemukan solusi dan hukum syara' dari permasalahan tersebut.

1 Erick Eckholm dan Kathleen Newlan, Wanita, Kesehatan, dan Keluarga Berencana, (Jakarta: Sinar Harapan, 1984), 26.

2 Monique Shintani, et.al, “Aborsi Remaja Ngeri!", Majalah Detik, ed. 30 (25 Juni 2012), 9

${ }^{3}$ Majalah Detik, Juli 2012 


\section{Awal Kehidupan Manusia}

Untuk memahami awal kehidupan janin, berikut ini terdapat beberapa ayat al-Qur'an yang menjelaskan proses penciptaan manusia secara bertahap di antaranya adalah firman Allah Surat alHajj 22:5, Surat al-Mu'minûn 23:12-14, dan Hadits riwayat Bukhârî dan Muslim sebagai berikut:

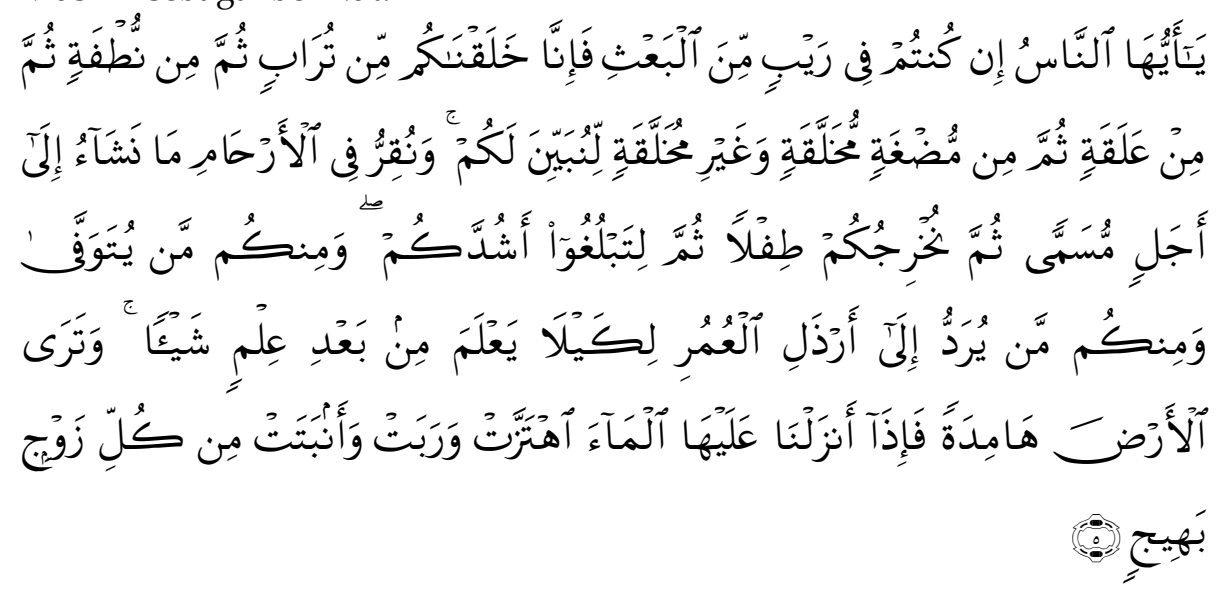

Hai manusia, jika kamu dalam keraguan tentang kebangkitan (dari kubur), maka (ketahuilah) sesungguhnya Kami telah menjadikan kamu dari tanah, kemudian dari setetes mani, kemudian dari segumpal darah, kemudian dari segumpal daging yang sempurna kejadiannya dan yang tidak sempurna, agar Kami jelaskan kepada kamu dan Kami tetapkan dalam rahim, apa yang Kami kehendaki sampai waktu yang sudah ditentukan, kemudian Kami keluarkan kamu sebagai bayi, kemudian (dengan berangsur-angsur) kamu sampailah kepada kedewasaan, dan di antara kamu ada yang diwafatkan dan (ada pula) di antara kamu yang dipanjangkan umurnya sampai pikun, supaya dia tidak mengetahui lagi sesuatupun yang dahulunya telah diketahuinya. Dan kamu lihat bumi ini kering, kemudian apabila telah Kami turunkan air di atasnya, hiduplah bumi itu dan suburlah dan menumbuhkan berbagai macam tumbuh-tumbuhan yang indah. ${ }^{4}$

${ }^{4}$ Departemen Agama RI, al-Qur'an dan Terjemahnya (Jakarta: Riels Grafika, 2009), 332. 


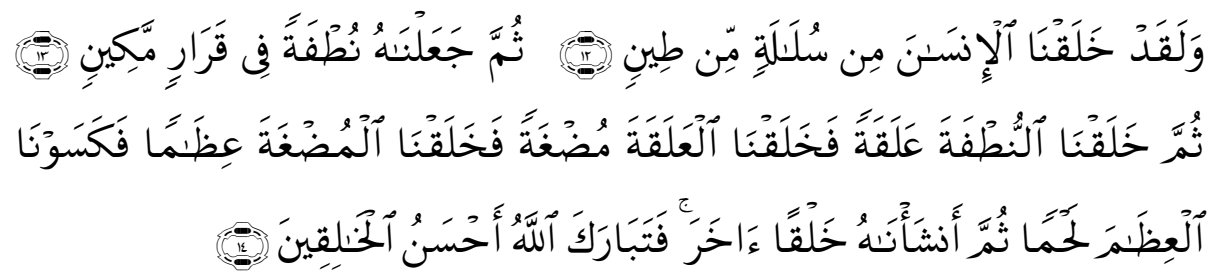

Dan sesungguhnya Kami telah menciptakan manusia dari suatu saripati (berasal) dari tanah. (12) Kemudian Kami jadikan saripati itu air mani (yang disimpan) dalam tempat yang kokoh (rahim). Kemudian air mani itu Kami jadikan segumpal darah, lalu segumpal darah itu Kami jadikan segumpal daging, dan segumpal daging itu Kami jadikan tulang belulang, lalu tulang belulang itu Kami bungkus dengan daging. Kemudian Kami jadikan dia makhluk yang (berbentuk) lain. Maka Maha Suci lah Allah, Pencipta Yang Paling Baik. ${ }^{5}$

$$
\begin{aligned}
& \text { إن احد كم يجمع خلقه في بطن امه اربعين يوما نطفت, بكون علقة مثل ذلك, ثم يكون } \\
& \text { مضغة مثل ذلك, ثم يرسل إليه الملك فينفخ فيه الروح رواه البخاري ومسلم }
\end{aligned}
$$

Benih setiap orang dari kamu terkonsentrasi di rahim ibu dalam bentuk setetes benih hidup (nuthfah) selama 40 hari, kemudian menjadi segumpal darah ('alaqah) selama waktu yang sama, kemudian menjadi suatu gumpalan daging (mudhghah) selama waktu yang sama, kemudian malaikat diutus kepadanya untuk menyawainya. (HR. Bukhari dan Muslim) ${ }^{6}$

Ayat dan dalil tersebut, menurut Sayyid Qutub, yang dikutip oleh Nasaruddin 'Umar, memberikan penjelasan tentang reproduksi manusia dengan melalui proses perkembangan secara bertahap sejak mulai dari tanah sampai pada tahap sempurna menjadi manusia sehingga manusia dalam dirinya terdapat tiupan ruh dari Allah.7 Secara sistematis, sebagaimana yang telah dijelaskan pada ayat tersebut, terdapat tahap pertumbuhan dan perkembangan janin dalam rahim, mulai dari tahap al-nutfah (sperma) atau setetes air mani.

Pertemuan sperma dan ovum ini lalu berdiam dalam rahim (uterus), yang dalam bahasa al-Qur'an diistilahkan dengan qarâr makîn. Menetapkan telur dalam rahim terjadi karena timbulnya villis,

\footnotetext{
${ }^{5}$ Ibid., 342.

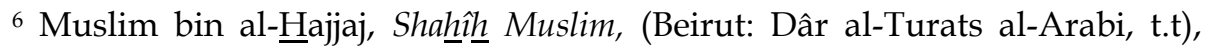
2036, nomor 2643.

${ }^{7}$ Nasaruddin Umar, et.al, Akhlak Perempuan, (Jakarta: Restu Ilahi, 2006), 147.
} 
yaitu perpanjangan telur yang mengisap zat yang dibutuhkan dari dinding rahim, seperti akar tumbu-tumbuhan yang masuk ke dalam tanah. Pertumbuhan semacam ini mengokohkan telur dalam rahim. ${ }^{8}$

Tahap selanjutnya yaitu al-'alaqah (sesuatu yang melekat atau gumpalan darah). Pertemuan sperma laki-laki dan ovum perempuan pada tahap awal mengakibatkan pembuahan sehingga terbentuk suatu zat (gumpalan darah) yang melekat pada dinding rahim, yang dalam bahasa al-Qur'an diistilahkan dengan 'alaqah. Istilah ini oleh sebagian ulama dipahami sebagai "segumpal darah". Berbeda dengan Sayyid Qutub, yang dikutip oleh Nasaruddin Umar, ${ }^{9}$ yang mengartikan 'alaqah sebagai "suatu zat yang melekat" pada rahim ibu. Perubahan atau peralihan dari nutfah ke 'alaqah terjadi ketika sperma laki-laki bercampur dengan ovum perempuan yang melekat pada dinding rahim, yang pada awalnya berbentuk zat yang kecil (nutfah saghîrah). Ia memperoleh makanan dari darah sang ibu.

Kemudian dalam tahap al-mudghah (berbentuk gumpalan daging); yaitu peralihan dari 'alaqah ke mudghah. Tahap ini terjadi pada saat seseuatu yang melekat pada dinding rahim ibu berubah menjadi darah beku yang bercampur. Setelah berbentuk gumpalan daging, maka perkembangan selanjutnya adalah proses terbentuknya tulang-belulang (tahap al-izhâm) kemudian tulang-belulang tersebut dikelilingi atau dibungkus dengan daging.

Tahap terakhir yaitu pemberian nyawa (nafkh al-rûh); Setelah melalui proses perkembangan manusia, mulai dari nutfah, 'alaqah, mudghah, sampai tahap al-izhâm, pertumbuhan sudah sampai pada tahap penyempurnaan dengan meniupkan ruh ke dalam jasadnya, hal ini membutuhkan proses selama 4 bulan (120 hari). ${ }^{10}$

\section{Aborsi}

Aborsi (Inggris: abortion, Latin: abortus) berarti keguguran kandungan. Dalam bahasa Arab,11 aborsi disebut isqât al-haml atau ijhâd, yaitu pengguran janin dalam rahim. Menurut istilah

\footnotetext{
8 Ibid., 148-149.

${ }^{9}$ Ibid., 149.

${ }^{10}$ Ibid., 149-152.

11 Ibid., 140.
} 
kedokteran, aborsi berarti pengakhiran kehamilan sebelum gestasi (28 minggu) atau sebelum bayi mencapai berat 1000 gram. ${ }^{12}$ Dalam istilah hukum, ${ }^{13}$ pengeluaran hasil konsepsi dari rahim sebelum waktunya.

Menurut Fact About Abortion, Info Kit And Women's Healt oleh Institue for Social, Studies and Action, Maret 1991, dalam istilah kesehatan aborsi didefinisikan sebagai penghentian kehamilan setelah tertanamnya telur (ovum) yang telah dibuahi dalam rahim (uterus), sebelum usia janin (fetus) mencapai 200 minggu. ${ }^{14}$ Aborsi dapat juga diartikan sebagai pengakhiran masa kehamilan atau hasil konsepsi sebelum janin hidup di luar kandungan. ${ }^{15}$ Sedangkan, Abdul Fadl Mohsin Ebrahim mengemukakan bahwa aborsi adalah pengakhiran kehamilan, baik secara tidak sengaja, spontan akibat kelainan fisik perempuan, atau akibat penyakit biomedical internal, maupun dengan cara yang disengaja melalui campur tangan manusia. ${ }^{16}$

Pendapat al-Ghazâlî yang dikutip oleh Masjfuk Zuhdi,17 mengartikan aborsi sebagai penghilangan jiwa di dalam janin. Ia membagi dua fase keadaan janin, yaitu fase kehidupan yang belum teramati yang ditandai dengan adanya proses kehidupan secara diam-diam dan fase kehidupan yang sudah teramati, yaitu ketika ibu atau orang lain dapat mendeteksi tanda-tanda kehidupan bayi dalam kandungan. Menurutnya, kedua fase tersebut harus dihormati dan dihargai sebagai suatu kehidupan bayi dalam kandungan. Hal yang sama juga dikemukakan oleh Mahmud Syaltut bahwa kehidupan terjadi sejak masa konsepsi, karena itu aborsi sejak masa konsepsi tidak boleh dilakukan.

Dari berbagai pengertian tersebut, dapat dipahami bahwa aborsi merupakan suatu proses pengguguran kandungan sebelum janin tersebut dilahirkan. Dengan kata lain, pengeluaran janin

12 Tn. Kapita Selekta Kedokteran, ed. 3, Media Aesculapius (Jakarta: FK UI, 2001), 206.

${ }^{13}$ Said Agil Husain Al-Munawar, et.al, Ensiklopedi Hukum Islam (Jakarta: PT. Ichtiar Baru Van Hoeve, 1997), 7.

14 USAID dan LBH APIK, Aborsi dan Hak Atas Pelayanan Kesehatan, Lembar Info Seri, 1.

${ }_{15}^{15}$ Masjfuk Zuhdi, Masail Fiqhiyah, Cet. VII, (Jakarta: Haji Masagung, 1994), 78.

${ }^{16}$ Abdul Fadl Mohsin Ebrahim, Aborsi, Kontrasepsi dan Mengatasi Kemandulan, Terj. Sari Mutia, Cet. I, (Bandung: Mizan, 1997), 125.

17 Zuhdi, Masail Fighiyah, 79. 
sebelum waktunya, baik itu spontan atau sengaja, dengan menggunakan obat-obatan tertentu atau dengan menggunakan jasa dukun pijat, maupun menggunakan alat-alat teknologi kedokteran.

\section{Aborsi dalam Perspektif Medis}

Di Indonesia, dokter tidak diperbolehkan melakukan pengguguran kandungan (abortus provokatus/therapeutic). Bahkan sejak awal akan menjalani profesi dokter, seseorang disumpah dengan Sumpah Dokter Indonesia yang didasarkan atas Deklarasi Jenewa yang menyempurnakan sumpah Hippokrates, di mana ia menyatakan diri untuk menghormati setiap hidup insani mulai dari saat pembuahan. ${ }^{18}$

IDI hanya akan melakukan aborsi berdasarkan indikasi medis yakni kehamilan yang membahayakan jiwa ibu dan janin. ${ }^{19} \mathrm{Hal}$ ini telah terdapat dalam kode etik IDI mengenai kewajiban umum pasal 7d: setiap dokter harus senantiasa mengingat akan kewajiban melindungi hidup makhluk insani. Pada pelaksanaannya apabila ada dokter yang melakukan pelanggaran, maka penegakan implementasi etik akan dilakukan secara berjenjang dimulai dari panitia etik di masing-masing rumah sakit hingga Majelis Kehormatan Etika Kedokteran (MKEK). Sanksi tertinggi dari pelanggaran etik ini berupa pengucilan anggota dari profesi tersebut dan sanksi administratif tertinggi adalah pemecatan anggota profesi dari komunitasnya.

Kehamilan yang boleh dilakukan aborsi oleh para medis karena adanya uzur adalah yang bersifat darurat di mana perempuan hamil menderita penyakit fisik berat seperti halnya kanker stadium lanjut, TBC dengan caverna dan penyakit-penyakit berat lainnya yang akan membahayakan nyawa ibu apabila tetap mempertahankan bayinya sampai lahir. Hal ini tidak terikat waktu, baik itu telah terjadi pembuahan atau lebih dari 40 hari, apabila secara medis terdapat indikasi mengancam nyawa ibu maka aborsi dapat

${ }^{18}$ Mirza Maulana, Penyakit Kehamilan dan Pengobatannya (Jogjakarta: KATAHATI, 2010), 78.

${ }^{19}$ Dyah Ratna Meta Novia, "IDI Takkan Pakai Pasal Akibat Perkosaan" Republika, 15-Agustus-15: http://www.republika.co.id/berita/nasional/umum/14/08/15/nacgue-iditakkan-pakai-pasal-akibat-perkosaan. (Diakses tanggal 02-Mei-2015) 
dilakukan.20 Walaupun demikian, bagi perempuan yang sejak awal sudah terindikasi penyakit fisik berat tersebut di atas, maka sebelum 40 hari kehamilan haruslah segera dilakukan tindakan aborsi melalui izin dari sang ibu dan keluarganya.

Dalam dunia kedokteran dikenal 3 macam aborsi, yaitu:

a. Aborsi Spontan/Alamiah atau Abortus Spontaneus, yaitu hilangnyajanin secara alamiah tanpa adanya intervensi manusia secara sengaja. ${ }^{21}$ Kebanyakan karena kurang baiknya kualitas sel telur dan sel sperma.

b. Aborsi Buatan/Sengaja atau Abortus Provocatus criminalis adalah pengakhiran kehamilan sebelum usia kandungan 20 minggu atau berat janin kurang dari 500 gram sebagai suatu akibat tindakan yang disengaja dan disadari oleh calon ibu maupun si pelaksana aborsi (dalam hal ini dokter, bidan atau dukun beranak). Aborsi bentuk kedua ini biasa disebut dengan isqat al-ikhtiyari (aborsi yang disengaja).

c. Aborsi Terapeutik/medis atau abortus provocatus theraupeticum adalah pengguran kandungan buatan yang dilakukan atas indikasi medis untuk menyelamatkan jiwa ibu yang terancam bila kelangsungan kehamilan dipertahankan. Aborsi ini di kalangan ulama disebut dengan isqath al-dharuri (aborsi darurat) atau isqath al-'ilajy (aborsi pengobatan). ${ }^{22}$

Dari berbagai macam aborsi di atas, para ulama sepakat dan tidak ada perbedaan bahwa aborsi jenis pertama atau aborsi spontan tersebut tidak haram karena memang tanpa kemauan atau kehendak dari yang bersangkutan. Dalam literatur bahasa Arab, aborsi spontan dikenal dengan al-isqât al-ma'fu yang berarti aborsi yang dimaafkan karena aborsi semacam ini terjadi di luar kemauan manusia.

Berikut beberapa cara yang dilakukan dalam praktik aborsi, yaitu:

20 Al-Ghufron Mukti dan Adi Heru Sutomo, Abortus, Bayi Tabung, Euthanasia, Transplantasi Organ, dan Operasi Kelamin dalam Tinjauan Medis, Hukum dan Agama Islam, cet-1 (Yogyakarta: Aditya Media, 1993), 10.

${ }^{21}$ Anang Haris Himawan, Bukan Salah Tuhan Mengazab; Ketika Perzinaan Menjadi Berhala Kehidupan (Solo: Tiga Serangkai, 2007), 53.

22 Zainal Abidin, Figh Kontemporer (Pamekasan: STAIN Pamekasan Press, 2010), 13-14. 
a. Abortus untuk kehamilan sampai 12 minggu biasanya dilakukan dengan MR/Menstrual Regulation yaitu dengan penyedotan (semacam alat penghisap debu yang biasa, tetapi 2 kali lebih kuat).

b. Pada janin yang lebih besar (sampai 16 minggu) dengan cara Dilatasi dan Curetage.

c. Sampai 24 minggu, di sini bayi sudah besar sekali, sebab itu biasanya harus dibunuh lebih dahulu dengan meracuni dia. Misalnya dengan cairan garam yang pekat seperti saline. Dengan jarum khusus, obat itu langsung disuntikkan ke dalam rahim, ke dalam air ketuban, sehingga anaknya keracunan, kulitnya terbakar, lalu mati.

d. Di atas 28 minggu biasanya dilakukan dengan suntikan prostaglandin sehingga terjadi proses kelahiran buatan dan anak itu dipaksakan untuk keluar dari tempat pemeliharaan dan perlindungannya.

e. Juga dipakai cara operasi Sesaria seperti pada kehamilan yang biasa. ${ }^{23}$

Cara-cara yang dipilih oleh si ibu juga bermacam-macam, di antaranya:24

a. Menggunakan jasa medis di rumah sakit atau tempat-tempat praktek

b. Menggunakan jasa dukun pijat

c. Menggugurkan sendiri kandungannya dengan alat-alat kasar dan atau melompat-lompat agar janinnya tergoncang hingga dinding pembungkus rahim pecah

d. Menggunakan obat-obatan tertentu Akibat yang bisa timbul pada perempuan yang melakukan aborsi adalah:

a. Usus dan rahim robek atau bolong, jika melakukan aborsi melalui pemasukan batang ke vagina.

b. Rahim jadi kering dan jaringan sehat di rahim berubah jadi jaringan ikat, jika melakukan kuret

c. Bisa muncul tumor di rahim, jika aborsinya tidak bersih

${ }^{23}$ Abdurrahman Al-Baghdadi, Emansipasi Adakah Dalam Islam, (Jakarta: Gema Insani Press, 1998), 58.

${ }^{24}$ Eckholm dan Newlan, Wanita, Kesehatan, 26-27. 
d. Pendarahan di vagina yang terus menerus, jika ada sisa janin atau plasenta yang tidak bersih dapat berbahaya bagi keselamatan ibu. Terkadang dibutuhkan pembedahan untuk menghentikan pendarahan tersebut.

e. Infeksi yang bisa terjadi di vagina, leher rahim, rahim sampai usus, jika alat aborsinya tidak steril.

f. Sepsis (keracunan darah), biasanya terjadi jika aborsi menyebabkan infeksi tubuh secara total yang kemungkinan terburuknya menyebabkan kematian

g. Kerusakan organ lain, saat alat dimasukkan ke dalam rahim, maka ada kemungkinan alat tersebut menyebabkan kerusakan pada organ terdekat seperti usus atau kandung kemih.

h. Berbagai macam penyakit kanker seperti halnya Kanker payudara (karena ketidakseimbangan hormon estrogen pada perempuan), Kanker indung telur, Kanker leher rahim, Kanker hati dan penyakit ganas lainnya.

i. Kematian, meskipun komplikasi ini jarang terjadi, tapi kematian bisa terjadi jika aborsi menyebabkan perdarahan yang berlebihan, infeksi, kerusakan organ serta reaksi dari anestesi yang dapat menyebabkan kematian.

j. Mengganggu kehamilan berikutnya, melakukan lebih dari satu kali aborsi akan meningkatkan risiko melahirkan prematur pada kehamilan berikutnya serta komplikasi lain seperti masalah pada mata, otak, pernapasan atau usus bayi. Selain itu juga dapat berakibat mandul/tidak mampu memiliki keturunan lagi (ectopic pregnancy) dan kelainan pada placenta/ari-ari (placenta previa) yang akan menyebabkan cacat pada anak dan pendarahan hebat pada saat kehamilan berikutnya. ${ }^{25}$

Perubahan mental perempuan yang pernah melakukan aborsi adalah:26

a. Menjadi lebih tertutup dan menarik diri dari kehidupan sosial

b. Mudah trauma dan sering mimpi buruk

c. Depresi dan sering mencoba bunuh diri

d. Kesulitan menikmati hubungan seks.

${ }^{25}$ Maulana, Penyakit Kehamilan, 69.

${ }^{26}$ Shintani, et.al, "Aborsi Remaja Ngeri!", 12. 
Dengan adanya mafsadat yang begitu banyak yang akan timbul jika melakukan aborsi maka sudah sepantasnya tindakan aborsi tidak diperbolehkan. Hal ini untuk mencegah adanya mafsadat-mafsadat lain yang akan timbul karena aborsi tersebut.

Dalam kaidah, ulama' merumuskan kaidah hukum sadd al$d z a \hat{i}^{\prime} a h$ yang tujuannnya adalah untuk menutup semua kemungkinan terjadinya kerusakan dan mafsadat. Penerapan kaidah tersebut digunakan untuk memungkinkan tercapainya maqâshid al-syarî'ah aldlarûriyyat (tujuan pokok hukum Islam). ${ }^{27}$ Jadi tindakan aborsi memang sudah seharusnya diharamakan demi menutup jalan terjadinya kerusakan dan tercederainya tujuan utama hukum Islam.

Selain itu, sebagai seorang dokter, sebelum melakukan praktik aborsi, mereka juga harus meminta pertimbangan tim ahli lainnya (ahli medis lain, agama, hukum dan psikologi), meminta persetujuan tertulis dari penderita, suami atau keluarga terdekatnya, dokumen harus lengkap dan prosedur tidak dirahasiakan. Syarat-syarat ini sesuai dengan tujuan utama dari profesi dokter yaitu menyelamatkan setiap hidup insani dan tetap dalam garis peraturan yang telah ditentukan secara prosedural.

Dalam hal ini, peraturan yang dibuat oleh IDI sesuai dengan pandangan para ulama dalam memilih alasan diperbolehkannya aborsi yaitu terdapat indikasi medis yang dapat membahayakan nyawa dari ibu. Sebab indikasi medis adalah satu-satunya faktor yang diperbolehkan dalam Islam dalam menghilangkan nyawa seseorang untuk menyelamatkan nyawa lain yang sudah jelas ada. Para ulama juga sepakat bahwa hukumnya boleh, sesuai dengan kaidah fiqh:

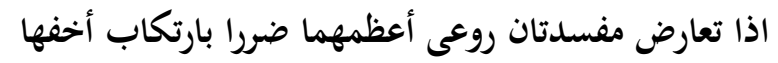

"jika berkumpul dua mudharat (bahaya) dalam satu hukum, maka dipilih yang lebih ringan mudharatnya" 28

27 Siti Musawwamah, "Akseptabilitas Regulasi Kriminalisasi Pelaku Kawin Sirri Menurut Pemuka Masyarakat Madura", al-Ihkam, Vol 8, No. 29 (Desember, 2013), 270. Lihat juga Y. Wahyudi, Hasbi's Theory of Ijtihad in the Context of Indonesia Fiqh, (Thesis MA McGill University of Canada, 1993), 56.

${ }^{28}$ Abdul Mudjib, Kaidah-Kaidah Ilmu Fiqh, (Jakarta: Kalam Mulia, 2001), 40. 
Berdasarkan kaidah tersebut, seorang perempuan dibolehkan menggugurkan kandungannya jika keberadaan kandungan itu mengancam hidupnya, meskipun ini berarti membunuh janinnya. ${ }^{29}$

\section{Aborsi dalam Perspektif Yuridis}

Aborsi telah dilakukan oleh manusia sejak berabad-abad lalu, namun saat itu belum ada Undang-undang yang mengatur tindakan aborsi. Peraturan mengenai aborsi mulai dikeluarkan pada tahun $4 \mathrm{M}$, sehingga telah terdapat larangan aborsi sejak saat itu. Undangundang tentang aborsi semakin mengalami perbaikan seiring dengan adanya revolusi dalam sikap masyarakat dan pemerintah yang saling bekerja sama menyampaikan aspirasi di berbagai dunia terhadap tindakan aborsi.

Di Indonesia, peraturan mengenai aborsi salah satunya terdapat dalam Kitab Undang-Undang Hukum Pidana Indonesia bab XIV tentang kejahatan kesusilaan Pasal 299 ayat (1) dinyatakan bahwa: Perbuatan aborsi yang sengaja atas perbuatan sendiri atau minta bantuan pada orang lain dianggap sebagai tindakan pidana yang diancam dengan hukum paling lama 4 tahun penjara atau denda paling banyak tiga ribu rupiah.

Pada Ayat (2) dinyatakan: Apabila yang berasal dalam aborsi tersebut adalah pihak luar (bukan ibu yang hamil) dan perbuatan itu dilakukan untuk tujuan ekonomi, sebagai mata pencaharian, maka hukumannya dapat ditambah sepertiga hukuman pada ayat (1) di atas dan apabila selama ini perbuatan itu dilakukan sebagai mata pencaharian, maka dapat dicabut haknya untuk melakukan mata pencaharian tersebut.

Selain itu, KUHP BAB XVIII tentang Kejahatan Terhadap Kemerdekaan Orang, pasal 346 menerangkan bahwa: Seorang perempuan yang sengaja menggugurkan atau mematikan kandungannya atau menyuruh orang lain untuk itu, diancam dengan pidana penjara paling lama empat tahun.

Pada pasal 347: Barang siapa dengan saja menggugurkan atau mematikan kandungan seorang perempuan tanpa persetujuannya, diancam pidana penjara paling lama dua belas tahun. Jika perbuatan itu mengakibatkan matinya perempuan tersebut, diancam dengan pidana penjara paling lama lima belas tahun.

${ }^{29}$ Ibid. 
Dan dalam Pasal 348: Tentang seorang yang melakukan pengguran atau mematikan kandungan dengan perstujuan wanita tersebut, diancam dengan pidana penjara paling lama lima tahun enam bulan, jika perbuatan itu mengakibatkan kematian wanita tersebut, dipidana penjara paling lama tujuh tahun.

Selanjutnya Pasal 349 menegaskan: Apabila yang melakukan kejahatan pasal 346, 347 dan 348 tersebut adalah seorang dokter, bidan atau dukun, maka pidananya ditambah dengan sepertiga dan dapat dicabut haknya untuk menjalankan pencarian dalam mana kejahatan itu dilakukan. ${ }^{30}$

Secara jelas dan tegas hukum di Indonesia sangat melarang perbuatan aborsi yang dilakukan secara sengaja, tanpa alasan darurat dan tanpa persetujuan dari para pihak. Sanksi tidak hanya akan diberikan kepada orang yang memiliki janin tersebut namun juga diberlakukan kepada orang yang telah membantu proses aborsi. Dalam hal ini pelaku praktek aborsi lebih berat sanksinya daripada yang meminta untuk diaborsi karena melakukan aborsi sama dengan pembunuhan pada janin apalagi jika nyawa ibunya tidak terselamatkan. Sebagaimana peraturan yang diberikan kepada para medis bahwa setiap dokter harus senantiasa mengingat akan kewajiban melindungi hidup makhluk insani.

Peraturan di Indonesia tak hanya berdasar pada KUHP semata, saat ini banyaknya lembaga pemerintahan juga menimbulkan berbagai macam peraturan yang bisa jadi berbeda antara peraturan yang satu dengan yang lainnya. Di samping KUHP, terdapat pula hasil keputusan tentang ketentuan umum Majelis Ulama Indonesia (MUI) Nomor 4 Tahun 2005 menetapkan 2 pokok alasan melakukan aborsi, yaitu: ${ }^{31}$

1. Darurat, suatu keadaan di mana seseorang apabila tidak melakukan sesuatu yang diharamkan maka ia akan mati atau hampir mati.

2. Hajat, suatu keadaan di mana seseorang apabila tidak melakukan sesuatu yang diharamkan maka ia akan mengalami kesulitan besar.

30 Kumpulan Kitab Undang-Undang Hukum: KUH Perdata, KUHP, KUHAP (Jakarta: WIPRESS, 2008), 507-508.

${ }^{31}$ Fatwa Majelis MUI Nomor 4 Tahun 2005 (Jakarta: t.p., 2005), 455. 
Dalam Keputusan tersebut tentang ketentuan hukum memutuskan salah satu diantaranya bahwa aborsi haram hukumnya dilakukan pada kehamilan yang terjadi akibat zina. Namun alasan hajat yang dijelaskan dalam putusan tersebut adalah 1) Apabila janin yang dikandung dideteksi menderita cacat fisik yang kalau lahir kelak sulit disembuhkan, 2) Kehamilan akibat perkosaan yang ditetapkan oleh tim yang berwenang yang di dalamnya terdapat antara lain keluarga korban, dokter dan ulama. Kebolehan dilakukannya aborsi ketika usia janin belum melebihi waktu 40 hari.

Selain itu dikeluarkannya Peraturan Pemerintah (PP) Nomor 61/2014 pada 21 Juli 2014 yang disahkan oleh Presiden Susilo Bambang Yudhoyono tentang kesehatan reproduksi untuk melaksanakan ketentuan Pasal 74 ayat (3), Pasal 75 ayat (4), Pasal 126 ayat (4), dan Pasal 127 ayat (2) Undang-Undang Nomor 36 Tahun 2009 tentang Kesehatan. PP ini kemudian dikenal luas oleh publik sebagai "PP Aborsi" karena memuat pasal yang memperbolehkan tindakan aborsi.

Pada PP No. 61/2014 Bab IV Indikasi Kedaruratan Medis dan Perkosaan sebagai pengecualian atas larangan aborsi, Pasal 31 (1) Tindakan aborsi hanya dapat dilakukan berdasarkan: a. Indikasi kedaruratan medis; atau b. Kehamilan akibat perkosaan. (2) Tindakan aborsi akibat perkosaan sebagaimana dimaksud pada ayat (1) huruf b hanya dapat dilakukan apabila usia kehamilan paling lama berusia 40 (empat puluh) hari dihitung sejak hari pertama haid terakhir. Pasal yang terkait dengan hal ini adalah Pasal 32 ([1) Indikasi kedaruratan medis sebagaimana dimaksud dalam Pasal 31 ayat (1) huruf a meliputi: a. Kehamilan yang mengancam nyawa dan kesehatan ibu; dan/atau, b. Kehamilan yang mengancam nyawa dan kesehatan janin, termasuk yang menderita penyakit genetik berat dan/atau cacat bawaan, maupun yang tidak dapat diperbaiki sehingga menyulitkan bayi tersebut hidup diluar kandungan. (2) Penanganan indikasi kedaruratan medis sebagaimana dimaksud pada ayat (1) dilaksanakan sesuai dengan standar.

Menurut Nafsiah Mboi (mantan Menteri Kesehatan RI), ${ }^{32}$ pelegalan aborsi untuk perempuan korban perkosaan dikarenakan

${ }^{32}$ Muhammad Iiqbal, "Nafsiah Mboi Menteri Kesehatan: Aborsi Lindungi HAM Perempuan", Republika, 14 Agustus 2014: 
pemerintah sering mendapat informasi bahwa korban memiliki trauma yang cukup panjang, masih di bawah umur dan mereka tidak siap untuk punya anak. Perempuan yang menjadi korban perkosaan harus menanggung beban psikologis dan material karena melahirkan anak yang seumur hidup dibenci dan pandangan tidak adil dari masyarakat yang menganggap sebagai pelacur atau diceraikan suaminya. PP ini juga untuk melindungi HAM perempuan yang diperkosa apakah dia akan mempertahankan kehamilannya akibat perkosaan tersebut atau tidak.

Jika semangat dari putusan Fatwa MUI dan PP tersebut adalah untuk melindungi kesehatan reproduksi sebagai hak dasar perempuan yang menjadi bagian dari Hak Asasi Manusia (HAM), maka itu adalah alasan yang berusaha melegalkan tindakan kriminal karena hak hidup yang lebih besar dan wajib dilindungi yaitu janin yang sudah dikaruniai oleh Allah SWT di dalam rahim perempuan walaupun itu adalah hasil dari perkosaan.

Fatwa MUI dalam hal kedaruratan ini nampaknya telah menerapkan kaidah fiqh berikut:

$$
\text { "Kemudhorotan-kemudhorotan itu membolehkan hal-hal yang dilarang"33 الضرورة تبيح المظورات }
$$

\section{Kemashlahatan}

Menurut Abdul Mudjib, yang membolehkan seseorang menempuh jalan yang semula haram, itu adalah karena kondisi yang memaksa. Manakala keadaannya sudah normal, maka hukum akan kembali menurut statusnya. Oleh karena itu, wajar apabila syara' memberi batas di dalam mempergunakan kemudahan karena darurat itu, menurut ukuran daruratnya semata-mata untuk melepaskan diri dari bahaya.

Kemashlahatan manusia itu memiliki tingkatan-tingaktan. Tingkatan pertama lebih utama memelihara agama, tingkatan kedua memelihara jiwa, tingkatan ketiga memelihara akal, tingkatan

http://www.republika.co.id/berita/koran/halaman-1/14/08/15/naa5wa9nafsiah-mboi-menteri-kesehatan-aborsi-lindungi-ham-perempuan. (diakses tanggal 02 Mei 2015)

${ }^{33}$ Mudjib, Kaidah-Kaidah Ilmu Figh, 36. 
keempat memelihara keturunan dan tingkatan kelima memelihara harta. ${ }^{34}$

Sehingga wajar jika nyawa ibu lebih diutamakan ketika menjadi suatu darurat untuk melakukan tindakan aborsi demi menyalamatkan nyawa ibu.

Namun dalam keadaan hajat, di mana seseorang diperbolehkan melakukan tindakan aborsi sebelum janin berusia 40 hari dikarenakan akan lahir cacat genetik atau perkosaan, maka hal ini sulit untuk dapat diterapkan sebab dapat diketahuinya janin tersebut mengalami cacat genetik hanya dapat dilakukan dengan memeriksa air ketuban. Sedangkan adanya air ketuban tersebut baru ada ketika usia kehamilan sudah mencapai 4 bulan. ${ }^{35}$

Peraturan Pemerintah seharusnya dapat mengetahui dampak dari tindakan aborsi terhadap kesehatan reproduksi perempuan, karena dampak negatif setelah dilakukannya aborsi tersebut bisa mengakibatkan hal yang fatal seperti kematian sehingga PP ini bukan menjadi solusi atau wadah kesehatan reproduksi perempuan melainkan bisa menimbulkan pelegalan dari pembunuhan, tak hanya pada janin namun juga pada ibunya. Peraturan ini dapat menyebabkan berbagai masalah baru seperti halnya tenaga medis yang cenderung pragmatis dan bahkan menyimpang, dan mencegah praktik aborsi menggejala terutama di kalangan remaja yang semakin banyak melakukan seks bebas.

UU No 23 tahun 2002 tentang Perlindungan Anak Pasal 1 telah menjamin keselamatan anak sejak di dalam kandungan hingga usia 18 tahun. ${ }^{36}$ Dalam hal ini, tidak ditemukan unsur yang cukup layak untuk membenarkan penghilangan nyawa terhadap seorang anak hanya karena dikandung akibat perkosaan. Sebab sejak keberadaanya di dalam kandungan terdeteksi, seorang anak memiliki hak hidup yang diatur oleh undang-undang.

${ }^{34}$ Kamal Muchtar, Ushul Figh (Yogyakarta: PT. Dana Bakti Wakaf, 1997), 143144.

35 Yeni Fariyanto, Pandangan Majelis Ulama Indonesia (MUI) Terhadap Fatwa MUI Pusat Nomer 4 Tahun 2005 Tentang Aborsi (Skripsi, S1, Universitas Negeri Sunan Kalijaga, Yogyakarta, 2009), 2.

36 Undang-Undang Nomer 23 Tahun 2002 tentang Perlindungan Anak, (Jakarta: t.p., 2002), 3 . 
Gangguan mental korban peerkosaan, bisa diantisipasi dengan terapi atau rehabilitasi mental agar si korban siap menerima keberadaan bayi yang dilahirkan. Mutia Ribowo dalam acara konferensi pers HILO School Drawing Competition 2015 mengatakan, ${ }^{37}$ art psychotherapy merupakan bentuk treatment psikologi menggunakan seni sebagai media. Art Psychotherapy juga bisa digunakan untuk mengobati trauma. Penghapusan trauma terhadap peristiwa yang baru saja terjadi jauh lebih cepat dari pada trauma lama yang tak ditangani.

Aborsi merupakan tindakan pidana yang berakibat menghilangkan kesempatan hidup bagi bayi. Allah SWT telah memberikan karunia-Nya kepada seorang perempuan berupa janin yang akan menjadi bayi dan manusia sebagai makhluk paling sempurna dari ciptaan-Nya. Sperma yang telah mengalami masa konsepsi yaitu bergabung dengan ovum adalah awal dari adanya tanda-tanda kehidupan. Tanda-tanda kehidupan itulah yang sudah mulai harus kita lindungi eksistensi dan keselamatannya karena hal itu merupakan kehendak Allah untuk menciptakan manusia seperti apapun bentuknya. Kondisi bayi yang diketahui cacat telah Allah atur dan takdirkan untuk lahir di dunia karena disetiap ciptaan-Nya pastilah telah Ia karunia kelebihan dan hikmah dibalik kekurangannya. Dia memberikan amanah kepada manusia untuk merawat bayi tersebut, dan membunuhnya adalah perbuatan zalim sesuai dengan firman-Nya dalam Q.S al-Isra' (17): 31-33:

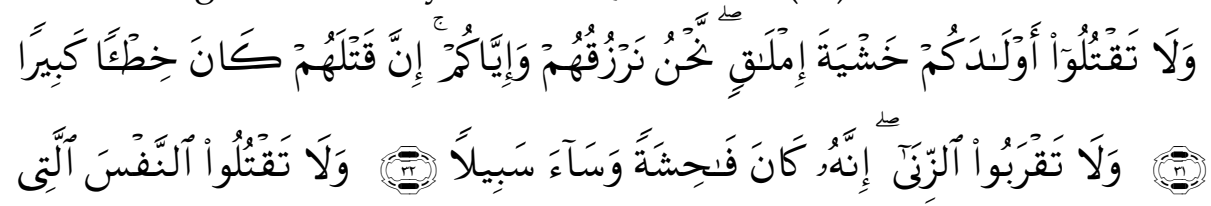

${ }^{37}$ Dyah Ratna Meta Novia, “ Ini Cara Hilangkan Trauma Korban Kekerasan Seksual”, $\quad$ Republika, $16 \quad$ Juni 2015 : http://nasional.republika.co.id/berita/nasional/hukum/15/06/16/nq132cini-cara-hilangkan-trauma-korban-kekerasan-seksual. (diakses tanggal 02 Mei 2015) 


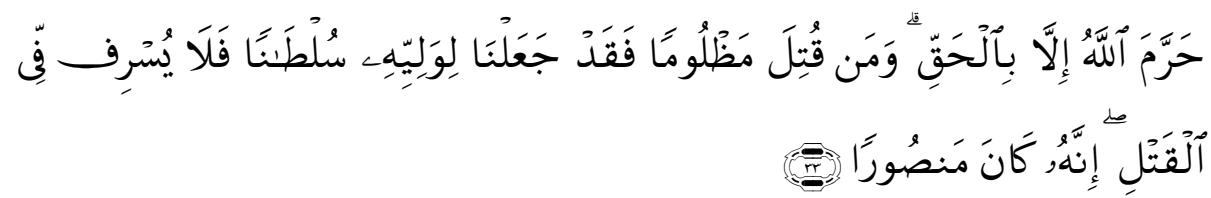

"Dan janganlah kamu mendekati zina; sesungguhnya zina itu adalah suatu perbuatan yang keji dan suatu jalan yang buruk. Dan janganlah kamu membunuh jiwa yang diharamkan Allah (membunuhnya), melainkan dengan suatu (alasan) yang benar. Dan barangsiapa dibunuh secara zalim, maka sesungguhnya Kami telah memberi kekuasaan kepada ahli warisnya, tetapi janganlah ahli waris itu melampaui batas dalam membunuh. Sesungguhnya ia adalah orang yang mendapat pertolongan". ${ }^{38}$

Dari ayat tersebut manusia diperingatkan untuk tidak mendekati zina, karena dari mendekati akan cenderung terjadi perbuatan zina. Hal ini bersambung dengan tindakan perkosaan yang akhir-akhir ini sering terjadi. Sering kali perkosaan terjadi karena adanya kesempatan yang diberikan oleh perempuan karena tidak menjaga aurat dan tidak menggunakan penutup aurat yang sesuai dengan syari'at Islam. Selain itu, Allah juga mengharamkan membunuh bayi tanpa alasan yang syar'i sedangkan alasan karena menghindari lahirnya anak cacat sama halnya dengan tidak menghargai ciptaan Allah dan tidak percaya akan Kekuasaan-Nya.

Dari ayat di atas secara tersirat telah terjawab hukum aborsi akibat perkosaan. Allah sama sekali tidak mengizinkan manusia untuk membunuh bayi yang telah dikaruniai oleh-Nya tanpa alasan yang benar, yaitu alasan medis atau mengancam nyawa sang ibu sebagaimana yang telah dipaparkan oleh para ulama di atas. Perkosaan memanglah hal yang tidak diinginkan terjadi oleh perempuan, namun kehamilan yang didapat merupakan kehendak Allah untuk menjaga dan merawat bayi tersebut.

Allah SWT. berfirman dalam Q.S Nuh 71:13-14:

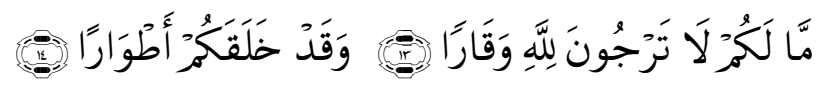

"Mengapa kamu tidak percaya akan kebesaran Allah? Padahal Dia sesungguhnya telah menciptakan kamu dalam beberapa tingkatan kejadian."39

${ }^{38}$ Departemen Agama RI, al-Qur'an dan Terjemahnya, 285.

${ }^{39}$ Ibid, 571. 
Hadirnya kehamilan diawali oleh keberhasilan spermatozoa dalam melakukan fertilisasi terhadap sel telur (ovum) yang terjadi di dalam tuba falopi, bersamaan dengan proses hormonal yang mengakibatkan perubahan secara fisiologi maupun fisik. Melalui bantuan kontraksi otot pada dinding rahim, akan terjadi seleksi spermatozoa untuk mendekati ovum yang berjumlah 200.000.000300.000.000 spermatozoa namun hanya 300-500 spermatozoa yang berhasil melintasi tuba falopi untuk mengerubungi ovum. ${ }^{40}$ Menurut Guyton yang dikutip oleh Kiptiyah dalam bukunya Kasih Sayang Allah Dalam Rahim Ibu, di jelaskan bahwa dari banyaknya spermatozoa yang berhasil mengerubungi ovum tersebut, hanya seekor spermatozoa yang diperlukan untuk fertilisasi ovum. ${ }^{41}$

Allah SWT telah menunjukan kekuasaan-Nya dari setetes air mani yang dipertemukan dengan sel telur untuk melakukan pembuahan yang kemudian menghasilkan zigot dan berkembang menjadi embrio di dalam dinding rahim. Embrio ini dapat tumbuh dan berkembang dengan adanya proses implantasi setelah adanya penebalan dinding rahim yang tujuannya untuk mempertahankan kehamilan agar tidak terjadi keguguran. Allah SWT. berfirman dalam Q.S al-Zumar 39:62,

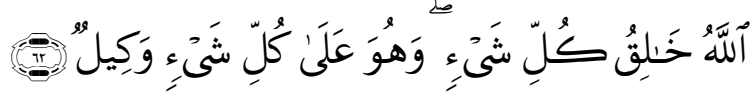

"Allah menciptakan segala sesuatu dan Dia memelihara segala sesuatu." 42

Plasenta diciptakan Allah SWT secara bertahap dengan ukuran yang sesuai dengan kebutuhan makhluk ciptaan-Nya. Penciptaan plasenta ini sebagai alat transportasi zat-zat makanan yang dibutuhkan untuk perkembangan dan pertumbuhan embrio secara proporsional dan ideal. Plasenta yang telah terbentuk pada minggu ke-2 mulai menjalankan fungsinya sebagai transportasi nutrisi dari ibu ke embrio juga berfungsi untuk menghasilkan human Chorionic Gonadotropin (hCG). Allah maha melindungi dan

\footnotetext{
40 Kiptiyah, Kasih Sayang Allah Dalam Rahim Ibu, (Malang: UIN-Malang Press, 2009), 55.

${ }^{41} \mathrm{Ibid}, 56$.

${ }^{42}$ Departemen Agama RI, al-Qur'an dan Terjemahnya, 465.
} 
menertibkan semua penciptaan-Nya sebagaimana dalam firman-Nya Q.S Ibrahim 14:34,

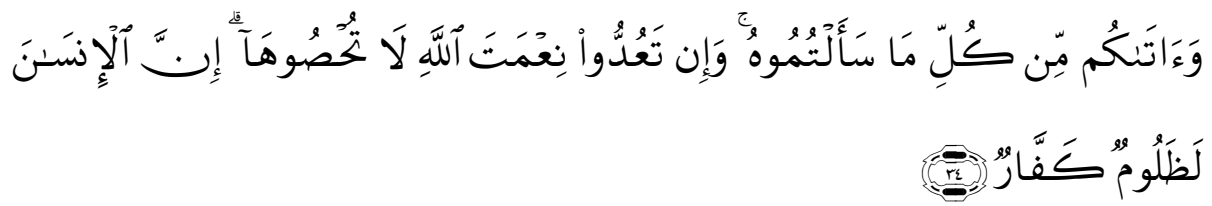

"Dan Dia telah memberikan kepadamu (keperluanmu) dari segala apa yang kamu mohonkan kepadanya. Dan jika kamu menghitung nikmat Allah, tidaklah dapat kamu menghinggakannya. Sesungguhnya manusia itu, sangat zalim dan sangat mengingkari (nikmat Allah)."43

Dalam berbagai riset disebutkan bahwa kehamilan pada korban perkosaan bervariasi dari kemungkinan nol sampai 2,2 persen. Dalam empat kasus tidak tercatat adanya kehamilan. ${ }^{4}$ Melihat statistik kehamilan akibat kejahatan perkosaan tersebut, nampak kemungkinan kecil terjadinya kehamilan. Walaupun demikian, generasi pemuda khususnya perempuan serta kesadaran pada masing-masing pemuda agar menjauhi perbuatan keji ini. Perbuatan ini hanya merupakan kenikmatan sementara yang justru mendatangkan mudharat yang lebih besar.

Apabila aborsi dilakukan karena sebab-sebab lain yang sama sekali tidak terkait dengan keadaan darurat, seperti untuk menghindarkan rasa malu, anak yang lahir akan mengalami cacat atau karena faktor ekonomi dan sebagainya, maka hukumnya haram. Alasannya adalah firman Allah SWT dalam Q.S. an-Nahl 16:58-59 dan al-An'âm 6:151.

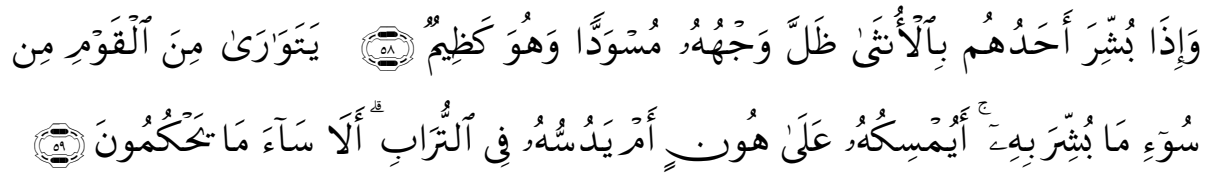

"Dan apabila seseorang dari mereka diberi kabar dengan (kelahiran) anak perempuan, hitamlah (merah padamlah) mukanya, dan dia sangat marah. Ia menyembunyikan dirinya dari orang banyak, disebabkan buruknya berita yang disampaikan kepadanya. Apakah dia akan

43 Ibid, hlm. 260.

${ }^{44}$ Ebrahim, Aborsi Kontrasepsi, 146. 
memeliharanya dengan menanggung kehinaan ataukah akan menguburkannya ke dalam tanah (hidup-hidup)? Ketahuilah, alangkah buruknya apa yang mereka tetapkan itu." 45

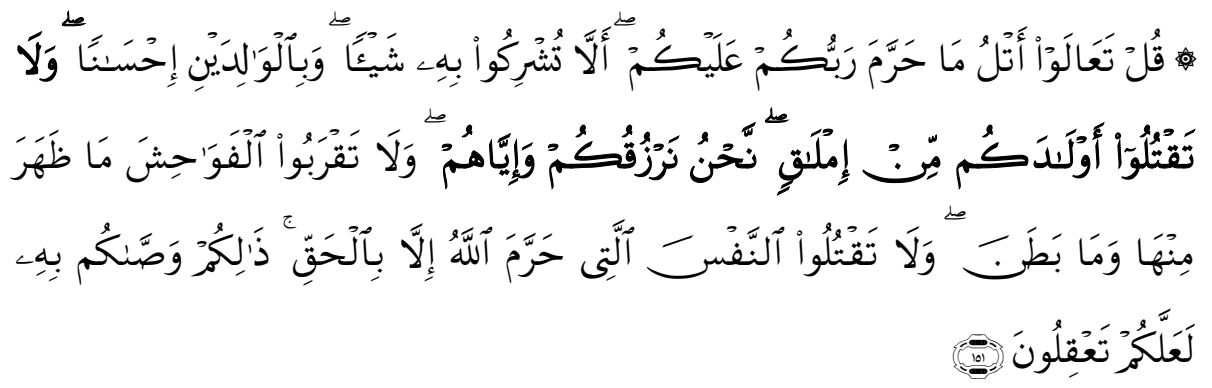

Katakanlah: "Marilah kubacakan apa yang diharamkan atas kamu oleh Tuhanmu Yaitu: janganlah kamu mempersekutukan sesuatu dengan Dia, berbuat baiklah terhadap kedua orang ibu bapa, dan janganlah kamu membunuh anak-anak kamu karena takut kemiskinan, Kami akan memberi rezki kepadamu dan kepada mereka, dan janganlah kamu mendekati perbuatan-perbuatan yang keji, baik yang nampak di antaranya maupun yang tersembunyi, dan janganlah kamu membunuh jiwa yang diharamkan Allah (membunuhnya) melainkan dengan sesuatu (sebab) yang benar". demikian itu yang diperintahkan kepadamu supaya kamu memahami(nya). ${ }^{46}$

Dalam surat al-Nahl di atas, Allah menceritakan kebiasaan orang Arab Jahiliah yang merasa malu mendapat anak perempuan, sehingga mereka sampai hati untuk menguburnya. Surat al-An'âm juga menjelaskan bahwa Allah telah memberikan jaminan rezeki kepada setiap makhluk yang telah diciptakan-Nya sehingga manusia tidak boleh ada rasa ketakutan akan hadirnya anak baru dalam kehidupannya karena hal itu adalah kehendak dari Yang Maha Menciptakan.

Mengenai hukum aborsi yang disengaja, para ulama sepakat melarang atau mengharamkan aborsi setelah ditiupkan ruh pada janin (setelah usia kandungan berumur 4 bulan atau 120 hari). Sebelum usia tersebut, para ulama berbeda pendapat:47

a. Menurut ulama Hanafiyah, diperbolehkan menggugurkan kandungan yang belum berusia 4 bulan, dengan alasan bahwa sebelum waktu 4 bulan belum ditiupkan ruh. Dengan demikian kehidupan insaniyah belum dimulai. Sebagian ulama

${ }^{45}$ Departemen Agama RI, al-Qur'an dan Terjemahnya, 273.

46 Ibid, 148.

${ }^{47}$ Abidin, Figh Kontemporer, 15-16. 
Hanafiyah berpendapat makruh apabila pengguguran tersebut tanpa udzur, dan jika terjadi pengguguran maka perbuatan tersebut perbuatan dosa.

b. Madzhab Mâlikîyah mengharamkan aborsi sejak terjadinya konsepsi (bertemunya sel telur dengan sperma di rahim ibu). Pendapat yang sama dengan Mâlikîyah dikemukakan oleh alGhazâlî dan ulama Zhâhirîyah yang mengharamkan aborsi sejak masa konsepsi. Dan menurut al-Ghazâlî mutlak keharaman tersebut. Sebagian ulama lainnya berpendapat bahwa dimakruhkan aborsi ketika usia kandungan 40 hari. Dan apabila usia kandungan mencapai 4 bulan, maka haram hukumnya melakukan aborsi.

c. Mazhab Syâfi'îyah berpendapat dimakruhkan aborsi ketika usia kandungan belum sampai 40 hari, 42 hari sampai 45 hari. Di samping itu, ulama Syâfi'îyah juga mensyaratkan adanya kerelaan kedua belah pihak. Dan apabila usia kandungan lebih dari 4 bulan maka hukumnya haram.

d. Menurut madzhab Hanabilah, sebagaimana pendapat ulama Hanafiyah, memperbolehkan aborsi ketika usia kandungan belum sampai 4 bulan atau belum ditiupkan ruh. Selebihnya diharamkan.

Ulama lain yang mengharamkan aborsi sebelum peniupan ruh adalah al-Ghazâlî dalam kitabnya Ihyâ Ulum al-Dînn ${ }^{48}$. Bahkan, Mahmud Syaltut, sebagaimana yang dikutip oleh Masjfuk Zuhdi, berpendapat bahwa sejak bertemunya sel sperma dengan ovum (sel telur) maka aborsi adalah haram, sebab sudah ada kehidupan pada kandungan yang sedang mengalami pertumbuhan dan persiapan untuk menjadi makhluk baru yang bernyawa yaitu manusia yang harus dihormati dan dilindungi eksistensinya. Akan semakin kejam dan besar dosanya apabila aborsi dilakukan setelah janin bernyawa.. ${ }^{49}$

Akibat hukum bagi pelaku aborsi setelah ditiupkannya ruh, menurut mayoritas jumhur ulama Syafi'iyah sepakat bahwa perbuatan itu termasuk dalam tindakan pidana (jarîmah) yang tidak halal dilakukan oleh seorang Muslim sebab perbuatan tersebut sama

48 al-Ghazâlî, Ihyâ' 'Ulûm al-Dîn, Juz II, (Kairo: Dâr al-్adîts, 2004), 67.

${ }^{49}$ Zuhdi, Masail Fiqhiyah, 81. 
halnya dengan pembunuhan manusia. Jumhur ulama Hanafî, Mâlikî, Syâfi'î dan Hanbalî termasuk ulama yang melarang aborsi pada setiap pertumbuhan janin tanpa alasan dan ulama kontemporer seperti Mahmûd Syalthûth.50 Menurut Yûsuf Qaradhawî pelaku harus dikenakan hukuman diyat jika bayi itu lahir kemudian mati. Dan denda harta yang lebih ringan dari diyat jika bayi itu lahir dalam keadaan mati. Denda itu wajib dibayar oleh pelaku yang terlibat dalam tindakan aborsi. Bisa dokter, dukun atau perempuan itu sendiri. ${ }^{51}$

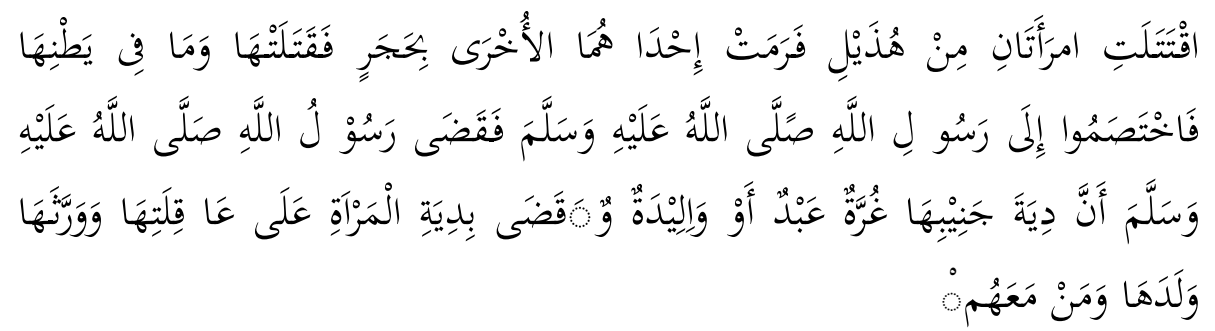

"Dua orang perempuan suku huzail berkelahi. Lalu satu dari keduanya melemparkan batu kepada yang lain hingga membunuhnya dan (membunuh pula) kandungannya. Kemudian mereka melaporkan kepada Rasulullah. Maka, beliau memutuskan bahwa diyat untuk (membunuh) janinnya adalah (memberikan) seorang budak laki-laki atau perempuan." (HR. al-Bukhârî dan Muslim dari Abû Hurayrah) ${ }^{52}$

Setiap manusia memiliki hak untuk hidup. Hanya Allah yang berhak untuk memberikan keputusan di antara makhluk-makhlukNya. Termasuk yang diharamkan ialah membunuh diri sendiri, dan pengecualian dengan hak ialah pembunuhan-pembunuhan yang terjadi dalam peperangan dengan syarat-syarat tertentu pula. Maka dalam tafsir al-Azhar disebutkan lima perkara yang haram dilanggar dan wajib dilaksanakan yaitu, Pertama, hubungan dengan Allah; Kedua, hubungan dengan kedua orang tua; Ketiga, hubungan dalam memelihara anak keturunan; Keempat, memelihara kesucian diri dari melakukan perbuatan zina dan Kelima, memelihara kesucian diri dari

\footnotetext{
${ }^{50}$ Mahmûd Syalthûth, al-Fatwâ (Kairo: Dâr al-Syûrâ, t.t.), hlm. 40.

51 Yûsuf al-Qardlawî, Fatwa-Fatwa Kontemporer, terj. AS-AS Yasin (Jakarta: Gema Insani Press, 1996), hlm. 779.

52 `Abd Allâh bin`Abd al-Rahmân al-Bassam, Tawdlih al-Ahkâm min Bulugh alMarâm (Lebanon: Mu`assasah al-Khidamat al-Thiba`iyyah, 1994), hlm.185.
} 
melakukan pembunuhan.53 Terkait dengan hal ini, maka dapat dikatakan dalam kasus perkosaan telah melanggar hukum Allah, mengecewakan harapan kedua orang tua, merusak hubungan anak keturunan serta menodai diri dengan perbuatan yang tercela.

Islam memiliki prinsip, bahwa pencegahan lebih diutamakan, begitupun dalam kasus pemerkosaan. Tetapi bila langkah-langkah pencegahan telah diambil tetapi perkosaan tetap terjadi, maka Islam menganjurkan agar korban segera mendapatkan pertolongan medis untuk mencegah segala kemungkinan terjadinya kehamilan. Pendapat ini diperkuat dengan pandangan Qurthubi yang yang mengatakan bahwa air mani bukanlah sesuatu yang pasti (yaqinan) dan tidak ada konsekuensinya jika perempuan segera mengeluarkannya sebelum ia menetap dalam rahim. ${ }^{54}$

Namun yang perlu diperhatikan bahwa jika aborsi karena perkosaan dilegalkan, maka akan banyak perempuan yang hamil dari hasil hubungan gelap dan ingin melakukan aborsi menggunakan alasan perkosaan. Sehingga dalam membuktikannya harus melalui proses yang panjang dengan meminta keterangan dari kepolisian dan medis dan hal ini tidak cukup hanya 40 hari untuk mendapatkan pembuktian tersebut, sehingga jika dihubungkan dengan kebolehan dalam fiqh di atas maka aborsi bagi korban perkosaan harus dilakukan sebelum air mani menetap dalam rahim yang hanya membutuhkan proses yang singkat yaitu kurang dari 40 hari, begitu juga dengan kebolehan yang dikecualikan dari Fatwa MUI dan PP 61/2014 yaitu maksimal aborsi tersebut dilakukan sebelum 40 hari sehingga pengecualian ini tidak mungkin dapat dilakukan tanpa adanya penetapan dari Kepolisian bahwa telah terjadi perkosaan karena untuk menetapkan kasus tersebut membutuhkan proses yang panjang.

Dari analisis di atas perlu kita perhatikan dalam menetapkan aturan tentang legalisasi aborsi karena ketika peraturan tersebut yang bertujuan untuk perlindungan namun pada akhirnya akan dapat menimbulkan kejahatan baru yaitu membunuh janin yang

53 Hamka, Tafsir al-Azhar, Jilid 3, (Singapura: Pustaka Nasional PTE LTD, 2007), 2264.

${ }^{54}$ Abû 'Abd Allâh Muhammad ibn Aḥmad al-Anshârî al-Qurthûbî, al-Jâmi' fî Ahkâm al-Qur'ân, (Kairo: Maktabah al-Wabah, 1967), 8. 
diharamkan Allah SWT dan mengakibatkan tindakan pelecehan seksual semakin mudah dilakukan serta dijadikan alasan dari perbuatan perzinaan.

\section{Penutup}

Aborsi dalam medis hanya akan dilakukan jika terindikasi penyakit yang mengancam nyawa ibu jika kehamilan tersebut masih dipertahankan. Pada Fatwa MUI No 4 Tahun 2005 membolehkan aborsi dalam keadaan darurat dan hajat, di mana hajat yang dimaksud adalah jika terdapat indikasi anak lahir cacat permanen serta hamil akibat perkosaan, begitu juga dengan PP No. 16 Tahun 2014 melarang aborsi kecuali dalam hal karena indikasi medis dan korban perkosaan. Dalam tinjauan hukum Islam, Kubu yang mengharamkan aborsi sejak masa konsepsi adalah Madzhab Mâlikî dan al-Ghazâlî, sedangkan Madzhab Hanafî, Syâfi'î dan Hanâbilah memakruhkan aborsi sebelum 120 hari.

Penulis berkesimpulan bahwa aborsi tidak dapat dilakukan jika tanpa alasan darurat yang mengancam nyawa ibu. Fiqh Islam menyebutkan aborsi perkosaan dapat dilakukan namun sebelum sperma bersatu dengan ovum. Dalam hal ini, hukum di Indonesia perlu memperhatikan kebolehan aborsi bagi janin yang terdeteksi cacat dan korban perkosaan. Adanya perbedaan peraturan antara medis, yuridis dan hukum Islam ini dapat mengakibatkan ketidakjelasan hukum bagi masyarakat Indonesia dan akan mengakibatkan terlindunginya para pelaku tindak kriminal akibat aborsi karena di satu sisi dia memiliki perlindungan hukum walaupun di sisi lain dia dapat dikatakan melanggar hukum. Begitu juga dengan para dokter yang ikut membantu tindakan aborsi.

\section{Daftar Pustaka:}

'Umran, 'Abd Al-Rahim. Islam dan KB. Jakarta: Lentera, 1997.

Abidin, Zainal. Figh Kontemporer. Pamekasan: STAIN Pamekasan Press, 2010.

Al-Munawar, Said Agil Husain, et.al. Ensiklopedi Hukum Islam. Jakarta: PT. Ichtiar Baru Van Hoeve, 1997.

Al-Baghdadi, Abdurrahman. Emansipasi Adakah dalam Islam. Jakarta: Gema Insani Press, 1998. 
al-Ghazâlî, Imâm. Ihyâ' 'Ulûm al-Dîn. Kairo: Dâr al-Hadîts, 2004.

Bassam, 'Abd Allâh bin 'Abd al-Rahmân al-. Tawdlih al-Ahkkâm min Bulugh al-Marâm. Lebanon: Mu’assasah al-Khidmat alThibầiyyah, 1994.

Departemen Agama RI. al-Qur'an dan Terjemahnya. Jakarta: Riels Grafika, 2009.

Ebrahim, Abdul Fadl Mohsin. Aborsi, Kontrasepsi dan Mengatasi Kemandulan. Bandung: Mizan, 1997.

Eckholm, Erick dan Kathleen Newlan. Perempuan, Kesehatan, dan Keluarga Berencana. Jakarta: Sinar Harapan, 1984.

Fariyanto, Yeni. Pandangan Majelis Ulama Indonesia (MUI) terhadap Fatwa MUI Pusat Nomer 4 Tahun 2005 Tentang Aborsi. Skripsi, S1, Universitas Negeri Sunan Kalijaga, Yogyakarta. 2009

Fatwa Majelis MUI Nomor 4 Tahun 2005. Jakarta: 2005.

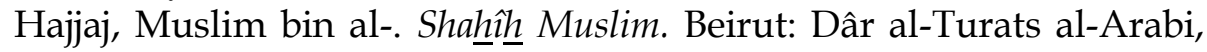
t.th.

Hamka, Tafsir al-Ashar. Singapura: Pustaka Nasional PTE LTD, 2007.

Kiptiyah. Kasih Sayang Allah dalam Rahim Ibu. Malang: UIN-Malang Press, 2009.

Kumpulan Kitab Undang-Undang Hukum: KUH Perdata, KUHP, KUHAP. Jakarta: WIPRESS, 2008

Maulana, Mirza. Penyakit Kehamilan dan Pengobatannya. Jogjakarta: KATAHATI, 2010.

Muchtar, Kamal. Ushul Figh. Yogyakarta: PT. Dana Bakti Wakaf, 1997. Mudjib, Abdul. Kaidah-Kaidah Ilmu Figh. Jakarta: Kalam Mulia, 2001.

Muhammad, Abu 'Abd Allâh ibn Ahmad al-Anshâri al-Qurthubî. alJâmi' fí Ahkâm al-Qur'ân. Kairo: Maktabah al-Wahbah, 1967.

Mukti, Al-Ghufron dan Sutomo, Adi Heru. Abortus, Bayi Tabung, Euthanasia, Transplantasi Organ, dan Operasi Kelamin dalam Tinjauan Medis, Hukum dan Agama Islam. Yogyakarta: Aditya Media, 1993.

Musawwamah, Siti, "Akseptabilitas Regulasi Kriminalisasi Pelaku Kawin Sirri Menurut Pemuka Masyarakat Madura", al-Ihkam, Vol 8, No. 29 (Desember, 2013).

Qardhawi, Yûsuf al-. Fatwa-Fatwa Kontemporer. terj. AS-AS Yasin. Jakarta: Gema Insani Press, 1996.

Shintani, Monique, et.al. “Aborsi Remaja Ngeri!”. Majalah Deti, edisi 30 (25 Juni 2012). 
Tn. Kapita Selekta Kedokteran, Media Aesculapius. Jakarta: FK UI. 2001. Umar, Nasaruddin, et.al. Akhlak Perempuan. Jakarta: Restu Ilahi, 2006. Undang-Undang Nomor 23 Tahun 2002 tentang Perlindungan Anak. Jakarta: Yp, 2002.

USAID dan LBH APIK. Aborsi dan Hak Atas Pelayanan Kesehatan. Lembar Info Seri.

Wahyudi, Y., Hasbi's Theory of Ijtihad in the Context of Indonesia Figh. Thesis MA McGill University of Canada, 1993.

Zuhdi, Masjfuk. Masail Fiqhiyah. Jakarta: Haji Masagung, 1994. 